811.112.2'373.611

811.163.41'373.611

https://doi.org/10.18485/sj.2019.24.1.7

БОЖИНКА М. ПЕТРОНИЈЕВИЪ ${ }^{*}$

Универзитет у Крагујевцу

Филолошко-уметнички факултет
Оригинални научни рад

Примљен: 09. 10. 2018.

Прихваћен: 15. 01. 2019.

\title{
ЦИРКУМФИКС - СТАТУС И ФУНКЦИЈА У НЕМАЧКОМ И СРПСКОМ ЈЕЗИКУ
}

У раду се анализирају творбене конструкције у немачком и српском језику са цииркумфиксом као непосредном конституентом (НК); ичиркумфикс као увезани префикс $+c y ф и к с$, придодат бази твори деривате, а у њима истовремено суфикс има функцију синтаксичке транспозиције, а префикс семантичке модификачије. У српском језику, иако ређе, суфикс може имати и функцију семантичке модификације. Најчешћи деривати као резултат тог процеса су у оба језика глаголи, нешто ређе именице $(\mathrm{N})$, изузетно ретке у немачком, чешће у српском, те адверби (прилози) у српском, продуктивнији у односу на именице.

Кључне речи: префикс, суфикс, циркумфикс, непосредна конституента, функције: семантичка модификација и синтаксичка транспозиција, семантички образац, синтаксички образац, деривација.

1. Увод. У „Језичном савјетнику”: > Društvo > Društvene znanosti > Jezikoslovlje (www.forum.hr/showthread.php?p=39121385 - 5.3.2018) наилазимо на опаску да је појам циркумфикс прилично „егзотичан”, да се у немачком језику такав афикс крије под називом конфикс и да може да се нађе у партиципу перфекта <нпр.. ge-frag-t> (уп. Куна 2006а:167); и не на крају питање да ли он (циркумфикс) уопште постоји, ако постоји префиксално-суфиксална творба. Овакво гледање на ичиркумфикс као нигде другде у литератури незабележено

* colic ristivoje < cristivoje@sbb.rs 
(не само у кроатистичкој, већ опште узев и у сербокроатистичкој, а добрим делом и германистичкој) отвара проблем суштине појма цииккумфикс. Наведена опаска ставља на овај начин под знак питања проблем статуса како циркум$\phi и к с а$ тако и конфикса јер се у примеру < ge-frag-t> ради о морфолошкој а не о творбеној структури. Она је предметом морфологије као научне дисципине и везује се за морфолошку категорију темпус. На другој страни конфикс је предметом новије дериватологије као научне дисциплине и спада у категорију везаних основичких морфема и нема додира са циркумфиксом. У нама доступној сербокроатистичкој дериватолошкој литератури скоро да се и не помиње назив изикумфикс, а у случају да се и помиње, своди се углавном на објашњење да је то „,афикс око основе, што би значило и испред и иза основе” (Шипка 2005: 28), без даљих објашњења, уз претпоставку да се под афиксом подразумева творбена категорија.

Као синоними овоме термину у литератури се јављају и други називи: дисконтинуирани морфеми / префиксално-суфиксална творба или дисконтинуирана афиксална комбинација - diskontinuirliche Affixkombination (уп. Fleischer/Barz 1992: 312, Donalis 2005: 114, Клајн 2003: 26 и сл.). Статус и функција циркумфикса остају у наведеној литератури делом ипак нетакнути и необјашњени. Нешто ближи чини нам се Моч (1999: 12) који уводи и задржава назив изиркумфикс; на њега се надовезују новији радови иако не следе увек његов семантички модел. И он (Моч) слично дефинише цииркумфикс као и претходници и види га као комбинацију суфикса и префикса који допуњавају основу/базу како на почетку тако и на крају ${ }^{1}$. Та комбинација постаје код њега видљива на творбеним обрасцима (Wortbildungsmuster), из којих се јасно ишчитава структура речи и функција њених конститутивних елемената као НК. Упореди:

[SM; (ge) -PFv- (e)] - das Geschreie, Gebrülle (Motsch, W. 1999: 426)

SM је ознака за семантички образаи (semantisches Muster), а скраћеница PFv означава вербалну базу. Поред наведеног обрасца су именички деривати као илустрација за наведени творбени образац, редак и једино могућ у номиналном пољу, у немачком језику, који помоћу наведеног циркумфикса [ge......e] од глагола (V) изводи именииу - дериват (N). Интересантном ће бити зато анализа корпуса са циркумфиксом и посебно поређење са српским језиком о коме скоро да немамо података.

2. Корпус. Циркумфикс-деривати као илустрација у тексту су у прегледаној литератури, напред назначеној и оној делом свесно изостављеној, прожети појединачним примерима, без структуре и текста. Та чињеница оте-

${ }^{1}$..., „und Zirkumfixe, d.h. Kombinationen aus Suffix und Präfix, ergänzen den Stamm sowohl am Anfang als auch am Ende". (Моч 1999: 12) 
жава могућност спознаје структуре самог цииркумфикс-деривата и функције његових конститутивних делова (НК). Отуда се корпус нужно наметнуо као база истраживања, посебно у српском језику, где једва да имамо било каквих података изузев код Клајна, који „,префиксално-суфиксалне твореницее” своди на именице $(\mathrm{N})$, илуструјући их следећим примерима: довратак, запећак, надимак, понедељак, заселак, напрстак и сл. (Клајн 2003: 26). Корпус кога смо случајним узорком успоставили не везујући се за конкретне текстне врсте открива већ при површној анализи неочекивано, а понегде и површно и погрешно тврђено како се цииркумфикси најчешће појављују у језицима који су богати префиксима као што су немачки и холандски (детаљније код Тафра и Кошутар 2009: 98). Узорак, пак, у немачком корпусу то не потврђује и приметно је нижи у односу на српски као далеко продуктивнији са разганатијом структуром у односу на немачки. Промер би био 1/3 у корист српског. О детаљима у следећим поглављима.

3. СТАТУС И ФУНКЦИЈА ЦИРКУМФИКСА. Полазну хипотезу овог рада чини спознаја да деривати, па и ови са циркумфисом, представљају јасно уређену хијерархијску структуру од две непосредне конституенте (НК) при чему 2. НК (префикс + суфикс) има функцију синтаксичке транспозиције, што значи да додат на базу мења врсту речи или семантичку класу; суфикси као део цзиркумфикса могу, мада ређе, и сами да имају функцију семантичке модификације попут префикса. Код цииркумфикса, иако је он део 2.НК он и даље задржава функцију синтаксичке трансозищије уз истовремену семантичку модификацију путем префикса. Тако спојени они се могу комбиновати само са одређеним базама (дакле рестриктивни принцип) и градити одређене творбене обрасце. Основа/база може по облику бити симплекс или структура. У овом случају разлагање је нешто компликованије.

Као илустрацију навешћемо два примера, по један у сваком језику, и описати их преко дијаграма како би релација била јаснија. Упореди:

1) Aber vielleicht war es das, was mich beunruhigte. (W. Herrndorf :Tschick 2015: 159)

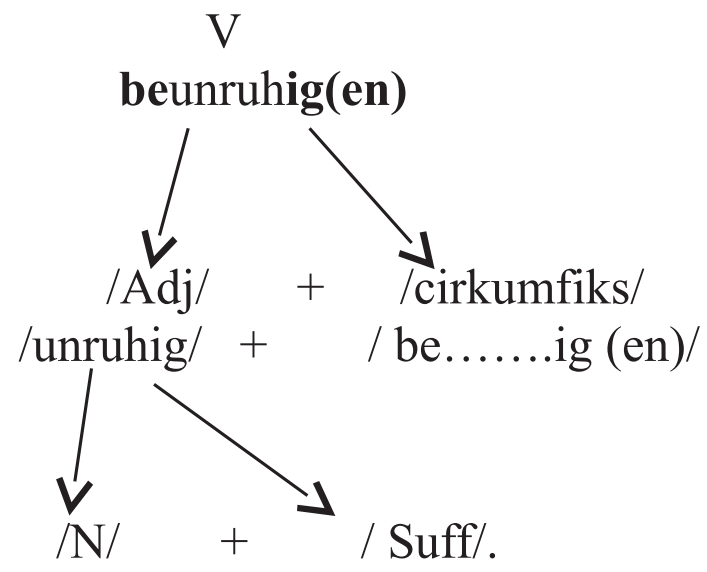




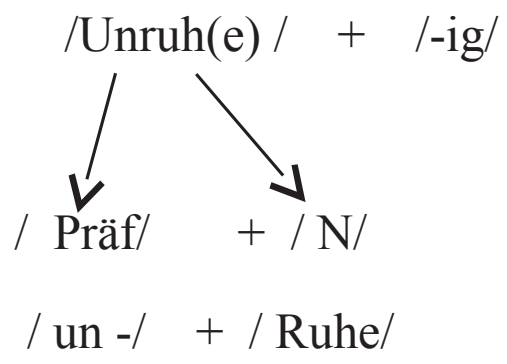

Глагол beunruhig(en) је на основу дијаграма јасно цииркумфиксни дериват као структура са Adj. као основом/базом која суфиксаиијом уз истовремену префиксаиију изводи глагол са одређеним семантичким обележјем. Суфикс се налази и даље, дакле, у функиији синтаксичке транспозищије и мења врсту речи $\boldsymbol{A} \boldsymbol{d j}>\boldsymbol{V}$. Сличну структуру пратимо и у српском:

2) И одједном чудно се нешто догодило, Као реч чаробна нека да се рекла,

Оживела је на зиду слика. (Десанка Максимовић ( http://zdm.nb.rs/1tom.pdf)
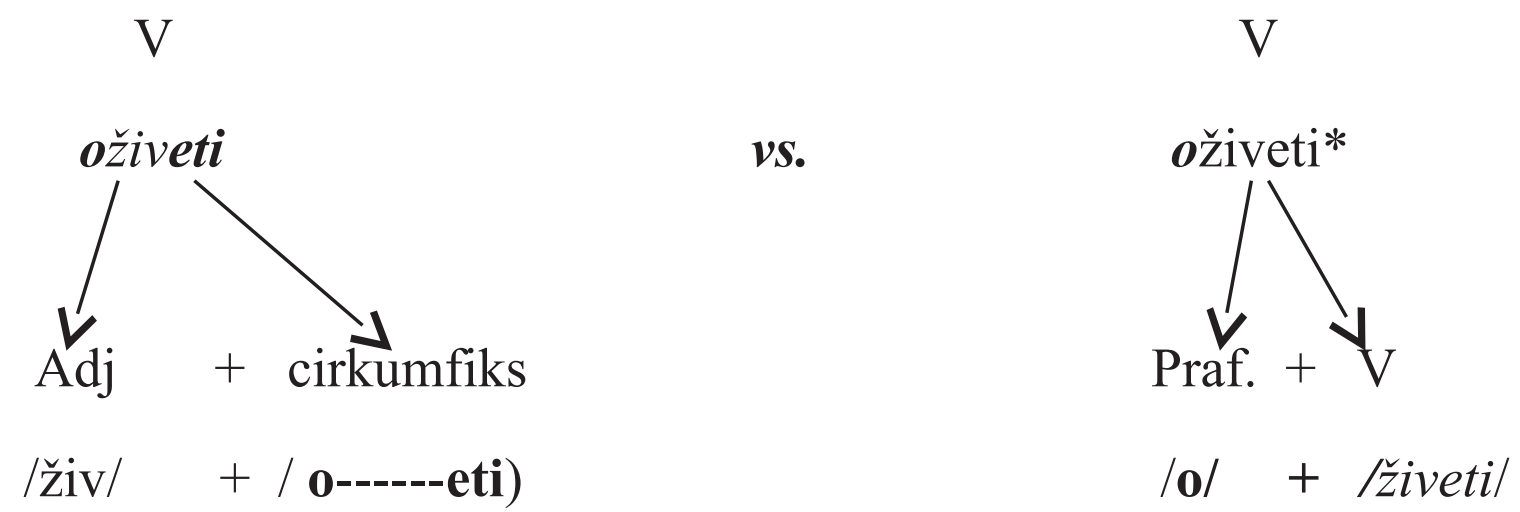

Иако су обе речи деривати, само прва је изведена циркумфиксом, друга је префигирана с префисом у функиији семантичке модификације уз глагол као 2. НК.

Увидом у корпус да се закључити како цииркумфикс може имати и функцију семантичке модификаиије у којој учествују како префикс тако и суфикс. Тај образац је веома продуктиван, среће се у српском и далеко је продуктивнији од немачког. Упореди:

3) Усамьен је и онај коме душу дам, yсамљен $а$ сам и ја, и узалуд молим. (Десанка Максимовић (http://zdm. nb.rs/1-tom.pdf) 
На дијаграму би ова структура изгледала на следећи начин:

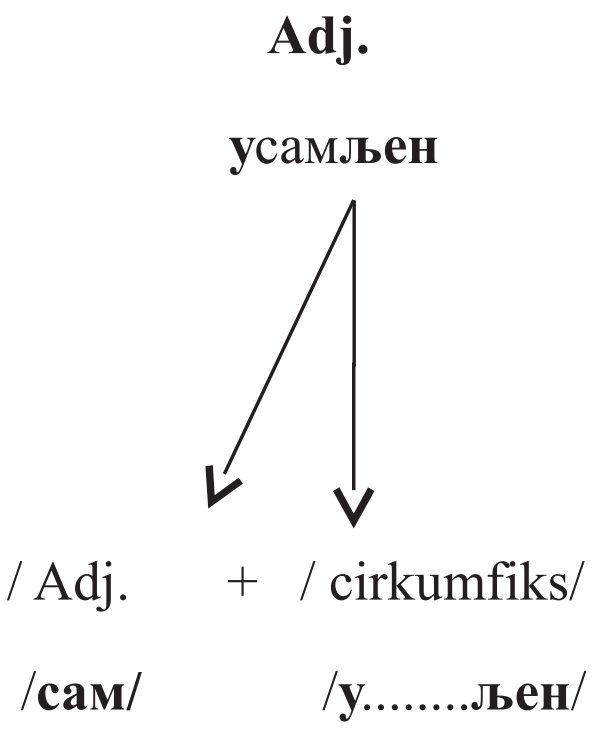

4. ЦИРКУМФИКСИ У НЕМАЧКОМ ЈЕЗИКУ. АнаЛИза корпусног материјала на немачком језику јасно показује да цииккумфикси не спадају у продуктивна средства творбе попут суфикса или префикса са одговарајућим дериватима. Код глаголских деривата Доналис (2005: 122) сматра да постоје само два иииркумфикса : be----ig $i$ in.....(is)ier а као базе према њој фунгирају искључиво именице (N) и придеви (Adj.) Циркумфикси су тако ограничени на базе, и функцију синтаксичке транспозичије уз истовремено наглашену семантичку модификачију.

4.1. ГЛАГОЛСКИ ЦИРКУМФИКС-ДЕРИВАТИ спадају у најфреквентнији тип цииркумфикс-деривата са структуром:

$$
\text { /N/ + / ver-/be-/ent-/ über- ........... (-en )/ > V, }
$$

коју многи поимају као вербални дериват са нултом-морфемом, -Ø, а -en узимају за граматичку морфему која маркира инфинитив (детаљније о томе код Фермерш 2011-2012). Анализа корпуса нас ипак упућује на закљчак да је -en полифункционална морфема, а да у функцији синтаксичке транспозиције има статус творбене морфеме. На овај закључак упућује и Турмаир (2000: 220) по којој и глаголи имају творбене морфеме у које она убраја -eln и -ern; Флајшер (1969: 286-291) ове сврстава у проширене суфиксе (Suffixerweiterung), а основа им је суфикс -(e)n. У даљем тексту, ослањајус́и се на Флајшера (1969) горе описану структуру бележимо са (-en), односно са -ig(en), -er(n), el(n) ако су део циркумфикса као код be ----ig(en) и сл.

$\mathbf{N}$ је иначе у нашем корпусу најчешћа база код глаголских циркумфикс-деривата, а то исто важи и за префикс ver- у комбинацији са суфиксом -(en) 
/-ig(en) као у: vergolden, verhexen, versumpfen, verwalden, verwüsten, и сл. Упореди:

4) Paul wohnt jetzt praktisch im Wald mit seiner Mutter und versumpft. (W. Herrndorf: Tschick 2015: 22)

5) ... war es wahrscheinlich auch tot, zerstört, von zwei Weltkriegen verwüstet. (W. Herrndorf: Tschick 2015: 174)

6) Schöne Wohndekorationen lassen sich einfach selbst vergolden (www. sueddeutsche.de > Gesellschaf - 29.04.2018)

7) Ist das ein aus der Kindheit rührendes Rollemodell? Geht es um Wildsein, wollt ihr jemanden verhexen. (https://www.google.rs/ search?biw=1366\&bih=651-29.04.2018 - 29.04.2018)

8) „Unser Ziel ist es, das Gebiet so nah wie möglich in seinen ursprünglichen Zustand zu bringen”, so Lüken. „Damit wollen wir verhindern, dass es weiter verwaldet." (https://www.weser-kurier.de/.../osterholzerkreisblatt_artikel,-Raus-a...-10.03.2018)

Далеко ређе у корпусу се срећу и други горе наведени префикси који са суфиксом (циркумфикс) придодати бази $\mathbf{N}$ творе вербалне деривате. За разлику од префигираних глагола, њихов број је овде далеко мањи. По правилу реч је о онима који спадају у орнативне глаголе, па отуда и префикс be- као у:

$$
\text { /N/ + / be-........(-en), -ig(en) / > V }
$$

Илустрације ради упореди:

9) Doch der Arzt bescheinigte mir schließlich, dass ich mich vergiftet hatte«, erinnert sich Acosta... (https://jungle.world/artikel/2017/.../arbeitskampf-auf-den-Plantagen - 10.03.2018)

10) ... bedenken Sie bitte, dass die Geburt dem Standesamt angezeigt werden muss und dass das Standesamt verschiedene Papiere von Ihnen benötigt, um die Geburt zu beurkunden. (www.nauen.de/dienstleistung/anzeigen/ $\mathrm{id} /$.../geburt,-beurkunden.ht... - 10.03.2018)

Нешто ређе у корпусу се јавља и префикс ent- као антоним од ver- и be- у примерима попут:

11) Abzugsprämie soll Dörfer entvölkern (www.spiegel.de > Politik > Deutschland - 12.03.2018)

12) Aus Wäldern werden Wüsten Und es erklärt, warum es möglich ist, dass das Land Schritt für Schritt nahezu komplett entwaldet wird, ohne dass jemand etwas dagegen sagt. (www.heiko-gaertner.de/kommentar_142112.03.2018) 
са структуром:

$$
\text { /N/ + / ent- ......... -(e)n, er(n) / > V }
$$

Појединачно могући су и други префикси, али изузетно ретко, који чине цииркумфикс попут über- у примеру:

13) Natürlich, die Benzinpumpe überbrück(e)n. (W. Herrndorf: Tschick 2015: 116: Tschick)

По фреквентности приближно глаголским дериватима са N-базом у корпусу се срећу и ииркумфикси са Adj као базом. Међу префиксима се и даље срећу ver- и be-, а са њима конкуришу и префикси er- и ent-, који у комбинацији са вербалним суфиксом творе циркумфикс, а заједно придодати бази Adj. образују вербалне циркумфикс-деривате. Творбена структура ових деривата дала би се описати на следећи начин:

$$
\text { /Adj. / + / ver-/be-/er-/ent- ...... (-en), -el(n), - er(n)/ > V }
$$

Упореди:

14) Der Schaffner: Nur, wenn Sie die mitreisenden Damen nicht belästigen! (Eulenspiegel 2006: 40)

15) „Oh”, sagte Herr K. und erbleichte. (Wolfgang Herrndorf 2015: 53 : Tschick)

16) Glücklicherweise konnte er sich der Erschaffenen sicher sein, dass diese Vorzeit nicht verblödelt wurde. (https://books.google.rs/ books?isbn $=3842359292-21.03 .2018$ )

17) Sie kann und wird unsere Gesellschaft bereichern, wenn es uns gelingt, diejenigen, die zu uns kommen und bleiben werden, rasch zu integrieren. (https://www.morgenpost.de > New Articles - 21.03.2018)

4.2. ИМЕНСКИ ЦИРКУМФИКС-ДЕРИВАТИ. Увидом у немачки корпусни материјал наилазимо на потврду да су у творбеном систему немачког језика могући али изузетно ретки и ичиркумфикс-деривати код именица $(\mathrm{N})$, што тврде и Флајшер и Барц². Овај образац познаје само један ицикумфикс, и то као комбинацију само једног префикса $(\mathbf{G e}-)$ и једног суфикса (-e), који као друга НК [циркумфикс Ge........e] придодат искључиво глаголу као бази/основи, твори именске деривате са неактивним суфиксом у функиији синтаксичке транспозиције. База може бити глагол (транзитивни и интранзитивни), а искључене су следеће групе глагола : рефлексивни, префигирани, модални и сл. Детаљније о овоме код Флајшер/Барц (2012: 266). Као илустрација могу да послуже следећи примери:

${ }^{2}$ „Die Modelle der Zirkumfixderivation sind beim Substantiv nur schwach entwickelt” (Флајшер/Барц 2012: 118). 
18) ... jedenfalls begegneten wir auf dem ganzen Weg durchs Gelände nur Schafen und Kühen. (Wolfgang Herrndorf 2015: 173: Tschick)

19) Vom Bett aus konnte ich das Meer sehen und Nachts hörte ich das Getöse der Wellen. (https://www.holidaycheck.de > ... >bewerten $-13.03 .2018)$

Из корпусног материјала лако се ишчитава да база именских циркумфиксних деривата може бити искључиво глагол, што потврђује горе изнету тезу,те би структура овог творбеног обрасца гласила:

$$
/ \mathbf{V} / \mathbf{N} /+/ \mathbf{G e}-\ldots . . .-\mathbf{e} />\mathbf{N}, \text { das, }
$$

а може се срести и код најпродуктивнијих структура: Gefrage, Gelache, Gelaufe, Gelese, Geschreibe, Getanze са транзитивном и интрансиривном глаголском базом, како јаких тако и слабих глагола. Детаљније о овоме код Флајшера 1969: $170-172$.

Других циркумфикса, посебно суфикса као његовог дела, нема па је тако немачки творбени систем далеко сиромашнији и мање креативан у односу на српски, бар кад су изведенице у питању.

5. ЦИРКУМФИКСИ У СРПСКОМ ЈЕЗИКУ. Циркумфикси у српском језику бележе сличан творбени образац као и немачки али далеко продуктивнији и креативнији. То се јасно може закључити на основу анализе српског корпусног материјала, а овај показује да се наведена тврдња односи како на број и врсту база у поређењу са немачким језиком, тако и на број и врсту префикса и су$\phi и к с а$, спојених у циркумфикс. Искључивањем структуралне методе из описа деривата са ииркумфиксом као парафразе неретко у литератури доводи до погрешних закључака и интерпретација. У том контексту Т. Билешић (2010: 29 ) се позива на Бабића (2002: 563) и указује како он разликује и прилошке циркумфикс-деривате са суфиксима: -це, -ище, -имке (продуктивни) те -ке, -ашке, -ачке, ушке (слабије плодни): наглавце, наглавачке, потрбушке, оберучке и сл. Ове деривате срећемо и код Клајна (2003: 376) али као други тип образца - сложено-суфиксални дериват (Zusammenbildung) - без икаквог објашњења. Парафразом наведених деривата долази се јасно до предложне фразе или конструкције PrepP (на главу, по трбуху, с обе руке...) као 1. НК или базе на коју се додају напред наведени суфикси. Овај поступак упућује на закључак да адверби не познају деривате са ииркумфиксом. Анализа српског корпусног материјала ипак указује на појаву тог творбеног обрасца у српском творбеном систему: / $\mathbf{N}+$ /po.....no/ > посмртно $),(\mathbf{N}+(\mathbf{u} . . . . . . . . . \mathbf{u})>\boldsymbol{y} и с т и н \mathbf{y})$, али на као посве ретку појаву. Клајн (2003: 266) дозвољава и могућност да циркумфикси у српском језику изводе и придевске деривате (бешуман, безрезервни, ванматерични, међудржавни, предизборни, прекобројан и др.). У свим овим примерима, међутим, изостаје префикс који би са суфиксом 
-(а)н или -ни творио адјективске деривате; без, ван, међу, пред, преко су у наведеним примерима чисти предлози који са именицама као основама творе предлошке фразе које даље са додатим суфиксима изводе деривате, образац сложено-суфиксалне творбе (Zusammenbildung), а што јасно проистиче из парафраза: без резерве, без иума, ван материце, међу државама, пред изборе, преко броја и сл. Појединачно, без системског карактера, у српском језику су ипак могући и придевски деривати са ц̧иркумфиксом као у следећој структури: /Adj + /u.....ljen/ > Adj. (yсамљен); превагу међутим имају као и у немачком глаголски и именички дериват и и наглашено прилошки деривати са цииркумфиксом .О њиховој специфичности у даљем делу текста.

\section{1. ГЛАГОЛСКИ ДЕРИВАТИ СА ЦИРКУМФИКСОМ У СРПСКОМ} ЈЕЗИКУ. Овај тип деривата у српском језику је изузетно продуктиван и захваљујући великом броју префикса у функиији семантичке модификације он је веома креативан. То претпоставља да ови деривати познају различите семантичке обрасие па самим тим и творбене обрасие. Опис сваког од њих би увелико прешао задате границе овог рада, па ће наша пажња у раду бити усмерена на површинску творбену структуру глагола са циикумфиксом. Префикси ће, без обзира на њихову семантичку различитост, бити набројани један поред другог и разврстани према бази, очито номиналној и адјективској као преовладавајућој. Примери попут: позлатити, искапити, закључати, уразумити, зауздати, забарикадирати, понемчавати, посрбљавати, постројити, поцуинковати, пролепшати се, оцртавати се, ослободити се дају се описати као:

$$
\text { /N/ + /po-, is-, za-, o-, u-, ob- .......... -ti, -iti, -irati-, -ovati / > V }
$$

Очигледно да је код овог обрасца преовлађући префикс по- сврставајући ове глаголске деривате у класу 'орнативних' попут ver- у немачком. Као синоним, али далеко ређе, може да се јави и префикс о-, кога Клајн (2003: 345) сврстава у најпродуктивније, а што не потврђује наш анализирани корпус. Пре би се могло рећи да он конкурише немачком префиксу be-. Илустрације ради наводимо неке од примера:

20) Из Панчева сам побегао у Праг јер су хтели даме помађаре, из Прага сам побегао за САДјер су хтели да ме понемче, а из САД ћу побећu ако неко од мене буде хтео да направи Американи̧а. (www.novosti. rs/.../репортаже.409.html:538511-Пупинов-гроб-од-20.03.2018)

21) Централна банка може да заузда инфлацију, ако би хтела и била спремна да плати цеену која није мала (www.vaseljenska.com/ ekonomija/cene-idu-svojim-putem-20.03.2018)

22) Одвијач се уразуми. (Г. Грас 1994: 9: Мачка и миш) 
23) Кажу, узбудљив је то посао јер умешношћу, иконама треба вратити време, поново позлатити векове Крушедола. (www.novosti. rs/.../peпортаже.409.html:246162-Pet-vekova-u-pozl..-20.03.2018).

24) Например, напуне се чаше, па је сваки дужан на дати знак да искапи чашy. (https://books.google.rs/books?id=0eFEBAAAQBAJ20.03.2018)

25) „, - драги Господ није вас без разлога обдарио талентима” (Грас, Г. 1994: 98: Мачка и миш)

Типични суфикс за ову групу деривата који од именица $(\mathrm{N})$ помоћу наведених префикса твори ииркумфикс-деривате глагола је-ити. Он истовремено у комбинацији са префиксима има функиију синтаксичке транспозииије. $\mathrm{He}$ треба искључити ни суфикс -ти, а посебно не суфикс страног порекла - ирати као у забарикадирати те суфикс-овати $y$ поцинковати и њему сличним глаголима.

Ништа мање продуктивни у српском језику нису ни глаголски цииркумфикс-деривати са Adj. као базом. Глаголи: подмладити, застаревати, опустети, омудрати, укрутети, омекиавати, отврдњавати показују структуру делом различиту у односу на глаголе са $\mathbf{N}$ као базом:

$$
\text { /Adj./ + /pod-, po-, o-, za-, u- ...... -eti, -iti, -ati, -evati , -avati / > V }
$$

То се пре свега односи на број и врсту суфиксалних морфема у функцији синтксичке транспозиције, изводећи глаголе од придева, уз истовремену семантичку модификаиију помоћу префикса, најчешће су и овде у питању: о-, по-, за-, под- иза којих стоје неретко неидентични семантички обрасци. Најчешћи је ипак онај који означава 'стање'. Илустрације ради упореди:

26) ...” Ове две сиене су ми - после детиғства, када је једина замислива сиена била санкање док се мокра одећа не укрути, и док се нос и прсти не следе-(n)остале синоним за планину... (vucinic.me/andjeliu-snegu/-29.04.2018: Мачка и миш)

27) ... и кад смо следећег лета мало омудрали, није се стидео пред нама ... (Грас, Г. 1994: 66: Мачка и миш)

28) У кривичном праву злочин геноцида не застарева, али у животима људи и у историји иивилизације исти се и не понавља, већ непрекидно траје. (https://www.kcns.org.rs/.../jasenovac-zlocin-koji-se-nesme-zaborav-21.03.2018)

29) Како подмладити кожу лица. https://betty.rs/kako-podmladiti-kozulica-29.04.2018) 
Посебно место у овој групи глагола заузимају суфикси -евати / -авати са аломорфима (омекшавати, отврдњавати) који немају кореспондент у немачком. Осим синтактичке транспозиције они имају и додатна семантичка обележја која маркирају акиионалност (Aktionsart) као несвршени глаголски вид, тачније као 'процес у трајању и понављању'.

У српском корпусу бележимо и глаголске деривате са циркумфиксом који за базу имају прилог (Adv). Синтаксичку транспозищију као функцију превођења прилога у глагол има само суфикс -ити; и он се јавља у комбинацији са префиксима које срећемо и у претходним групама попут: о-, об-, по (објаснити, појаснити, одаљити, поунутрити). Ови глаголи имају у немачком кореспонденте са префиксима ver- и er-, али са адјективским базама у адвербијалној функцији (адјункти). Њихова структура се зато може описати као:

$$
\text { /Adv./ + / ob-, o-, po-........-iti / > V }
$$

Илустрације ради упореди:

30) Ако не знаш да објасниш, ти уради. (https://www.bastabalkana. com/.../srpske-narodne-poslovice-mudros..-22.03.2018)

33) Он је вечерас појаснио своју изјаву и рекао да је то урадио „без трунке кајања". (www.novosti.rs/.../спорт.438.html:707510-Цветковић-појаснио-и...24.03.2018)

34) Треба теретни саобраћај одаљити од цеентра града али за туризам то не важи већ треба да буде што ближе иентру. (https://frfr.facebook.com/GradBeograd/posts-30.04.2018)

35) Пошто су поунутрили атлантистичку (аутоколонијалну) идеологију, они не виде да юихов бели господар смишљено уништава не само домаћу индустрију - убијајући тиме конкуренцију - већ да такође тежи и да маргинализује, поткопа и најзад сруши домаће високо образовање, домаће. (www.intermagazin.rs/kolonijalnapoliarhija/?lang $=$ cir -30.04 .2018 )

И не на крају, у корпусу српског језика бележимо глаголске деривате са циркумфиксом у функцији семантичке модификачије и глаголом као базом: очекивати, преждеравати и сл.). Суфикси -авати и -ивати маркирају акционалност као несвршени глаголски вид и означавају 'процес и понављање'. Структура која лежи овим глаголима у основи може се описати као:

$$
\text { /V / + / za-, o-, po-, pre- ....... -avati, --ivati/ > V }
$$

Префикси су уобичајени као и код других творбених образаца са цииркумфиксом и имају исту функцију - семантичке модификащије, неретко негативно конотиране. Упореди: 
34) Људи се „преждеравају”. (Политика, 24.03.2018: 04)

35) ... не можемо разумно очекивати да, ......., наиђемо на ма какве појаве, процесе или закономерности који би били неспојиви са могућношћу нашег властитог настанка. (Политика, 24.03.2018)

\section{2. ИМЕНИЧКИ ДЕРИВАТИ СА ЦИРКУМФИКСОМ У СРПСКОМ ЈЕЗИКУ.}

5.2.1. Именице: огранак, прирепак, окрајак, окрњак, посинак, подмладак, подлистак, повртьак спадају очигледно у именичке деривате са циркумфиксом у функцији синтаксичке транспозиције. С изузетком именица подмладак, окрњак већином је реч о именицама (N) са именицама као базом, али различите семантичке категорије у односу на њу. Творбена структура дала би се тако описати као:

$$
\text { / N/+ /o-, pri-, po- ...... -ak, -njak / > N }
$$

Овај творбени образац у српском језику далеко је фреквентнији него именице са циркумфиксом у немачком језику; њиховом успоредбом може се јасно устврдити да између њих не постоје кореспонденти али ни семантички еквиваленти. Истовремено пада за око да ови деривати у српском творбеном систему и нису тако продуктивни како то тврди Клајн (2003: 26), утолико пре што именице које он наводи (довратак, запећак, заселак, напрстак, нарамак, узглавак) и нису деривати са циркумфиксом већ спадају у сложено-суфиксалну творбу, коју јасно потврђују парафразе са предлошком фразом као базом и и 1. НК. Као илустрацију за N-базу наводимо овде само неколике примере:

36) Ова кост има тело и два окрајка. (jezik za medicinske škole: ULNA medicinskilatinski.blogspot.com/2018/03/ulna-24.03.2018)

37) Повртњак подсети Еда на башту његове стармајке: кромпир, келераба и лепа ката. (Луц Зајлер 2016: 44: Крусо) (превод: Никола Јорданов))

38) Дилема је хоће ли Краљево бити прирепак Чачка као што је некад било. (www.cacak.org.rs/Regionalna_privredna_komora-185-1 $-02.04 .2018)$

Примери:

39) Растављена вером на три окрњка, подељена политичком нуждом под разне власти ... (https://www.vesti.rs/Vesti/Anticki-Srbi-su-svidanasnji-Sloveni-01.04.2018)

\footnotetext{
${ }^{3} \mathrm{C}$ овим у вези сам Клајн примећује: „Старији граматичари тумачили су ове речи као изведене од синтагми предлог + именица, али такве синтагме не би могле послужити као мотивација" (Клајн 2003: 27).
} 
40) Међутим, овом приликом бих, ипак, нагласак ставио на рад нашег подмлатка Омладинско-теренске јединице, јер на младима свет остаје. (www.politika.rs/sr/clanak/368262/Dobra-ruka-casnih-ljudi01.04.2018)

попут (39) и (40) спадају очито у именичке деривате са цзиркумфиксом у функцији сиинтаксичке транспозищије али су ређи у употреби због Adj. као базе.

5.2.2. Омању подгрупу именичких деривата са цииркумфиксом у српском творбеном систему чине именице у којима циркумфикс има функцију семантичке модификације. Овај образац не познаје нпр. творбени систем немачког језика. Примери који следе: сукрвица, суснежица, сумаглица, измаглица имају структуру:

$$
/ \mathrm{N} /+ \text { / su-, iz- ..... -ica / > N }
$$

Суфикс -ица у комбинацији са префиксом су-, синонимно и из-, не мења врсту речи деривата у односу на базу, нити мења њену семантичку класу. Истовремено овај ц̧иркумфикс фиксира семантички образац и основе и деривата као

$$
\begin{gathered}
\text { [N \& ŽENSKO] } \\
\text { 'рефреренти који су } N \text { и женско' }
\end{gathered}
$$

из чега даље проистиче творбени образац:

[SM; N- /su-, iz- ..... -ica/ Femininum]

Наведени семантички образац додатно је мотивисан и семом (предикат) 'слабо' што би га могло приближити и предикату [DIM (N)] (r). Илустрације ради упореди:

41) Слана измаглища распршених капи ударала им је у лище (Зајлер, Луц 2016: 243: Крусо)

42) Киша и суснежица у нижим пределима, а на планинама снег, знатно отежавају вожну ове вечери, саопитио је Ауто-мото савез Србије. (http://www.politika.rs/scc/clanak/394691/AMS-Kisa-susnezica-i-snegotezavaju-voznju-8.1.2019)

43) Неретко се појави необјашњив умор, понекад искашьвавање сукрвице или крви које увек води пацијента лекару. (www.politika.rs/scc/.../ Imunoterapija-ubija-celije-tumora-pluća-16.04.2018)

6. АДВЕРБИЈАЛНИ ДЕРИВАТИ СА ЦИРКУМФИКСОМ. ТВорбенИ систем немачког језика не познаје префиксе као НК у творби адверба, па утолико пре он искључује и циркумфикс као конститутивни елемент адвербијалних структура. Српски на другој страни богат је префиксима па аналогно томе и 
циркумфиксима. Примери: насуво, уживо, изнова, испрва, изјутра, накриво, издалека, полако, наглавце показују да адвербијални деривати са изиккумфиксом имају следећу структуру:

$$
\text { /Adj./N/ + /na-, u-, iz-, is-, po- ...... -a, -o, -ce / > Adv }
$$

Најфреквентнији су они адверби са адјективом (Adj) као базом и суфиксом -а у циркумфиксу у функцији синтаксичке транспозищије, а далеко ређи они са суфиксом -о. Примери са именицом (N) као базом су могући али ретки, као што је редак и суфикс -це. Илустрације ради упореди:

44) Његов отаи се бријао насуво. (Луц Зајлер 2016: 349: Крусо)

45) Рик је увек изнова пунио чаме, чаме обећаға, чаме утехе и чаме својеглавости. (Луц Зајлер 2016: 268: Крусо)

46) Брежуљак, кућа и дрвеће, издалека, налик на чемпресе, подсетили су Еда на јужначке пејзаже ... (Луц Зајлер 2016: 171: Крусо)

47) Преко пуне повриине пружала се ирвена, а преко тога још једна, жута, жуто-ирвено-ирна, и тек тада Ед је препознао слику наглавце окренуте заставе. (Луц Зајлер 2016: 173: Крусо)

7. ЗАКључАк. На основу спроведене анализе може се извести закључак да је творбени модел деривације уз помоћ ииркумфикса (увезана комбинација префикса и суфикса, испред и иза базе) у функцији синтаксичке транспозиције мање продуктиван у немачком језику, док је у српском потврђен висок степен продуктивности - са више префикса и више суфикса, најчешће у функцији синтаксичке транспозиције, допуштајући и семантичку модификацију. У немачком продуктиван образац овог типа представљају глаголски деривати са ииркумфиксом, и изузетно ретко именички деривати; девербалне деривате и номиналне деривате, продуктивне у српском творбеном систему, немачки не познаје.

\section{ЛИТЕРАТУРА}

Бабић 2002: S. Babić, Tvorba riječi u hrvatskome književnome jeziku. HAZU - Nakladni zavod Globus. Zagreb.

Билешић 2010: T. Bilešić, Prilozi u hrvatskome standardnom jeziku. (www.hrvatskijezik.eu/radovi/Prilozi_u_hrvatskome_standardnom_jeziku. pdf - poslednji uvid 19.04.2018)

Доналис 2005: E. Donalis, Die Wortbildung des Deutschen. Ein Überblick, 2., überarbeitete Auflage, Tübingen: Gunter Narr Verlag.

Клајн 2003: И. Клајн, Творба речи у савременом српском језику, Други део: Суфиксачија и конверзија, Београд. 
Куна 2006а: B. Kuna, Nazivlje u tvorbi riječi, Filologija, 46-47, (https://hrcak. srce.hr/file/35043- poslednji uvid 18.04.2018)

Моч 1999: W. Motsch, Deutsche Wortbildung in Grundzügen, Berlin: Walter de Gruyter.

Taфpa/Kошутар 2009: B. Tafra i P. Košutar, Rječotvorni modeli u hrvatskom jeziku, u: Suvremena lingvistika, 67, 87-107.

Турмаир 2000: M.Turmair, Vergleich in der Wortbildung, in: Barz/Schröder/Fix (2000): Praxis und Integrationsfelder der Wortbildungsforschung, Heidelberg.

Фермерш 2011-2012: K. Vermeersch, Die desubstantivischen ornativen Verben im Deutschen und Spanischen (https://lib.ugent.be/en/catalog/ rug01:001891471https://lib.ugent.be/en/catalog/rug01:001891471 $-03.05 .2018)$

Флајшер 1969: W. Fleischer, Wortbildung der deutschen Gegenwartssprache, Lepzig.

Флајшер/Барц 1992: W. Fleischer, I. Barz, Wortbildung der deutschen Gegenwartssprache. Unter Mitwirkung von Marianne Schröder, Tübingen: Max Niemeyer Verlag.

Флајшер/Барц 1995: W. Fleischer, I. Barz, Wortbildung der deutschen Gegenwartssprache, 2., durchgelesene und ergänzte Auflage, Tübingen: Max Niemeyer Verlag.

Флајшер/Барц 2012: W. Fleischer, I. Barz, Wortbildung der deutschen Gegenwartssprache. Berlin/Boston: De Gruyter.

Шипка 2005: D. Šipka, Osnovi morfologije. Prilog gramatici savremenog standardnogjezika. (https://www.scribd.com/document/340978081/DankoŠipka-Osnovi-morfologije-2005-pdf-poslednji uvid 19.04.2018)

\section{DER STATUS UND DIE FUNKTION VOM ZIRKUMFIX IM WORTBILDUNGSSYSTEM DES DEUTSCHEN UND DES SERBISCHEN}

\section{Zusammenfassung}

In der vorliegenden Arbeit wird an einem umfangreichen Belegmaterial des Deutschen und des Serbischen der Status und die Funktion vom Zirkumfix untersucht. In beiden Sprachsystemen erweist es sich als wortbildendes Morphem (Kombination von Präfix und Suffix vor und hinter der Basis); obwohl das Zirkumfix zur gleichen Zeit semantische und 
syntaktische Funktion aufweist, seine Hauptfunktion besteht darin, Zirkumfix-Derivate zu bilden. Inerhalb dieser Wortbildungsmuster haben wir mit Strukturen zu tun, die sich zum großen Teil in den beiden im Vergleich stehenden Sprachen unterscheiden; im Deutschen sind sie nur zum Teil produktiv, dank der syntaktischen Funktion von Suffixen; in dieser Funktion bilden sie meist verbale Zirkumfixderivate, und äußerst selten nominale Derivate, mit nur einem einzigen Suffix; im serbischen Worbildungssystem sind Zirkumfixe sehr produktiv und damit auch die Zirkumfixderivate; sie gehören verschiedenen Wortbbildungsmustern an, weil sie dank mehreren Präfixen auch mehrere semantische Muster bilden; Suffixe haben auch im Serbischen die Funktion syntaktischer Transposition, daneben auch die der semantischen Modifikation, die das Deutsche nicht kennt. Im Endresultat bilden die Zirkumfixe im Serbischen verbale, nominale und adverbiale Derivate, vereinzelt auch die adjektivischen.

Schlüsselwörter: Präfix, Suffix, Zirkumfix, unmitelbare Konstituente (UK), semantische Funktion, syntaktische Funktion, semantische Modifikation, syntaktische Transposition, das sementiche Muster, das Wortbildungsmuster.

Božinka M. Petronijević 